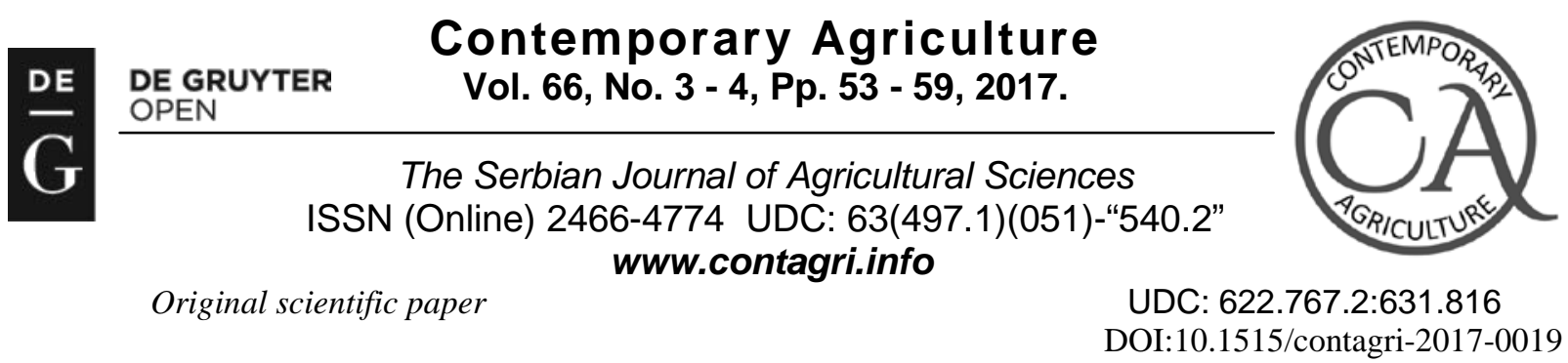

\title{
SUDANGRASS (Sorghum sudanense Pers.) IN THE RECLAMATION OF TECHNOSOLS IN THE STANARI MINING AREA
}

\author{
Nenad MALIĆ' $\dot{C}^{1}$ Una MATKO STAMENKOVIĆ ${ }^{2}$, Mihajlo MARKOVIĆ ${ }^{3}$ Zlatan KOVAČEVIĆ
}

\begin{abstract}
Summary: The surface exploitation of mineral raw materials inevitably changes the environment, thus resulting in soil degradation. This paper presents the results of growing sudangrass (Sorghum sudanense Pers.) in the reclaimed Deposol (technosols) in the Stanari Coal Mine area. Green manuring was the cultural practice used for sudangrass growing and land reclamation. The purpose of this research is to increase the amount of organic matter in the Deposol surface layer. The research was performed within a two-year period (2009-2010) at the experimental (technosol) site of the Stanari Coal Mine, located on the inside part of the overburden deposition site, near the Raskovac pit. The research of green manuring included a two-factor experiment with four replications. Two cultivars of sudangrass (Factor A) were used with three fertilization treatments (Factor $B)$. The soil analyses indicated a sandy and low fertile soil. The experimental plot Deposol showed favorable physical properties, whereas its chemical and biological properties proved very unfavourable. The highest yield of biomass (29.15 $t$ ha $\left.{ }^{-1}\right)$, as well as the dry matter (10.30 $\left.\mathrm{t} \mathrm{ha}^{-1}\right)$, was recorded in the cultivar 'Piper Sweet' (in 2009), which was completely treated with mineral fertilizers. The lowest yields of biomass (2.05 $\left.t \mathrm{ha}^{-1}\right)$ and dry matter (0.95 $\left.t \mathrm{ha}^{-1}\right)$ were observed in the cultivar 'Srem' in 2010. Statistically significant differences were found between the treatments applied, emphasizing that only certain cultivars of sudangrass and types of fertilization (encompassing reasonably high amounts of nitrogen) can significantly increase the amount of organic matter in Deposol.
\end{abstract}

Key words: biomass, cultivar, fertilization, Deposol, Stanari.

\section{INTRODUCTION}

At the beginning of the 21st century, the total area of damaged land in Bosnia and Herzegovina was over 20,000 ha. Mining activities in Bosnia and Herzegovina degrade another 3,000 ha of land each year (Resulović, 1999). Having researched the scope and direction of the biological phase of land rehabilitation in the largest three coal basins in the Republic of Srpska (Gacko, Ugljevik and Stanari), which jointly occupy around 2,000 ha, Malić et al. (2010) found that the reclamation process encompassed around $10 \%$ of the technogenic soils (technosols, mine soils). The primary goal of restoring damaged areas, resulting from surface exploitation, is to establish their functionality via managing the newly-formed technosols. Flat surfaces of overburden mine dumps (infertile material) have the potential for agricultural reclamation and production provided technical, cultural and biological reclamation practices are applied. It is necessary to reclaim these newly-created technosols of the Deposol type, and to enable their exploitation for specific purposes (Knežiček et al., 2006; Vujić et al., 2009).

Due to the disposal of overburden, the total amount of technosols will reach 4 million $\mathrm{m}^{3}$ of the solid matter, which is an area of more than 1,000 ha (Lončar et al., 2009), by the end of Stanari mine basin exploitation. The technology for continuous excavation of overburden has been adopted for the surface exploitation of lignite in the Stanari coal basin. This technology does not apply selective excavation and disposal of surface humus-accumulative soil horizons.

\footnotetext{
${ }^{1}$ Nenad Malić, PhD, EFT - Mine and TPP Stanari, 74208 Stanari, Republic of Srpska, Bosnia and Herzegovina.

${ }^{2}$ Una Matko Stamenković, MS, EFT Trade Belgrade, 11000 Belgrade, Serbia.

${ }^{3}$ Mihajlo Marković, PhD, Full Profesor, Zlatan Kovačević, PhD, Associate Profesor, University of Banja Luka, Faculty of Agriculture, 78000 Banja Luka, Republic of Srpska, Bosnia and Herzegovina.

Correspondig author: Nenad Malić, e-mail: mzmalic@gmail.com, 0038765340422
} 
Deposols (mine soils before reclamation) in Stanari have medium favourable physical and textural characteristics, whereas their chemical characteristics are poor (Malić, 2015; Malić and Marković, 2012). Considering the soil texture, the fraction of sandy loam prevails. The results of chemical analyses classify these Deposols into a low-class soil category regarding the organic matter content, available phosphorus and potassium, featuring weak-acid to acid soil reactions. The low content of organic matter in Stanari Deposols is the crucial issue to be resolved.

During the green manuring process, used to provide the surface soil layer with the fresh organic matter, sudangrass, out of five green manuring species (rye, vetch, field mustard, pea and sudangrass), proved the most effective in biomass production, accompanied by fertilization (Malić, 2010). The reclamation phase involving cultural practices was aimed at forming a more fertile surface layer of the disposed overburden. An increase in biomass production directly affects an increase in the content of organic matter in the Deposol surface layer at the overburden dumpsites of the Stanari lignite mine (Malić, 2010; Malić and Marković, 2012).

The genus Sorghum is highly tolerant to drought in all growth stages, thus it has become very important for the drier areas of continental climate and less fertile land. A significantly higher biomass production and the number of swath during the year can be achieved with the proper nitrogen nutrition under optimal moisture conditions (Zerbini and Thomas, 2003).

Forage sorghum (Sorghum vulgare L.) and sudangrass (Sorghum sudanense Pers.) are characterized by the diversity of use, favorable biological characteristics, low yield condition requirements, high and stable yield, and high quality of biomass, which renders these crops suitable for specific purposes (Glamočlija et al., 2010; Ćupina et al., 2007; Vučković, 1999).

In addition to sorghum and sudangrass, the breeding of interspecies hybrids of the two crops is present nowadays. Their genotypes are characterized by the high-quality biomass with a low content of pollutants. They regenerate well and produce large swaths (Berenji, 1988; Ostojić et al., 1992).

In relation to previous results, we continued the research of the effect of green manuring with sudangrass, depending on the variety and fertilization applied. The purpose of this study is to select the most productive sudangrass varieties and agricultural amelioration techniques to achieve maximum results under the given agroecological conditions.

\section{MATERIAL AND METHODS}

The research of green manuring with sudangrass was conducted in a test plot on the interior deposit side of the Raskovac surface pit at the Stanari lignite mine. The Stanari lignite mine is located in the north of the Republic of

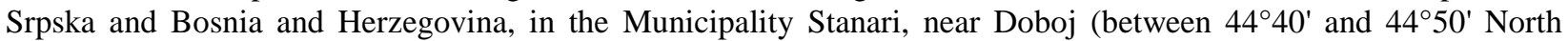
latitude and $17^{\circ} 45^{\prime}$ and $18^{\circ} 00^{\prime}$ East longitude).

The research was carried out during 2009 and 2010 (from April to August) as a two-factor experiment, which was based on 4 replications using a randomized complete block design. The basic experimental plot covered $10 \mathrm{~m}^{2}$ (5x2 m), and the distance between the blocks and plots was $1 \mathrm{~m}$ (x: 6,486,844.34; y: 4,957,642.54; z: $220 \mathrm{~m}$ ).

Sudangrass was sowed manually during the spring, with a seed rate of $35 \mathrm{~kg} / \mathrm{ha}$. During each sowing, a starter fertilizer was used at a dose of $75 \mathrm{~kg} / \mathrm{ha}$ of pure nutrients (N, P, K). The nitrogen fertilizer, at a dose of $54 \mathrm{~kg} / \mathrm{ha} \mathrm{N}$ (KAN, 27\% N), was used at the beginning of the jointing phenophase.

Factor A includes 2 treatments (two cultivars of sudangrass):

a1) 'Srem',

a2) 'Piper Sweet'.

Factor B includes 3 fertilization treatments (pure nutrients):

b1) N75+54P75K75,

b2) N75P75K75,

b3) NOP0K0 (control).

After the biomass measurements (August $5^{\text {th }} 2009$ and August 12 2010 ) in the phenophase of forming and soaking grains, sudangrass was incorporated by ploughing to a depth of 25-30 cm. The dry matter, representing the incorporated organic matter in Deposol, was measured based on the dried samples (measurements: August $27^{\text {th }} 2009$ and August $\left.08^{\text {th }} 2010\right)$.

The results obtained were examined by the analysis of variance (ANOVA). The significance of the differences between the basic factors and their interactions was tested with the F-test, whereas the differences between the mean values computed were determined by the LSD test.

Agroecological conditions: The experimental soil belongs to the Deposol type (Resulović and Čustović, 2007). According to the WRB classification (World Reference Base for Soil Resources, 2014), these substrates are determined as technosols (mine spoils or mine soil = disposal sites of the coal mining materials). Sudangrass was 
grown in the test plot formed during 2006 and 2007. The Deposol examined indicated a sandy loam texture and quartz mineral composition.

The results of the chemical analyses of the soil surface layer showed acid reactions ( $\mathrm{pH}$ in $\mathrm{KCl} 5.0$ ) at a depth of 0-30 cm. Considering the content of the easy accessible phosphorus (1.3 mg P2O5/100 g of soil), potassium (2.6 mg $\mathrm{K} 2 \mathrm{O} / 100 \mathrm{~g}$ of soil) and soil organic matter (1.6\%), this Deposol is classified as a soil with poor fertility. Nitrate is found in trace amounts $(0.01 \% \mathrm{~N})$, which, in addition to the lack of organic matter, causes a weak biological activity.

The basic climate indicators (precipitation and air temperature) within the two-year experimental period are shown in Table 1 and 2.

Table 1. Average monthly precipitation within the two-year experimental period at the Stanari Coal Mine (mm)

\begin{tabular}{|c|c|c|c|c|c|c|c|c|c|c|c|c|c|}
\hline \multirow{2}{*}{ Year } & \multicolumn{12}{|c|}{ Month } & \multirow{2}{*}{$\sum$} \\
\hline & I & II & III & IV & $\mathrm{V}$ & VI & VII & VIII & IX & $X$ & XI & XII & \\
\hline 2009 & 44 & 35 & 81 & 41 & 51 & 112 & 36 & 118 & 74 & 55 & 83 & 84 & 815 \\
\hline 2010 & 89 & 76 & 98 & 60 & 230 & 272 & 93 & 95 & 142 & 90 & 90 & 70 & 1406 \\
\hline
\end{tabular}

Table 2. Average air temperatures within the two-year experimental period at Stanari Coal Mine $\left({ }^{\mathrm{O}} \mathrm{C}\right)$

\begin{tabular}{|c|c|c|c|c|c|c|c|c|c|c|c|c|c|}
\hline \multirow{2}{*}{ Year } & \multicolumn{12}{|c|}{ Month } & \multirow{2}{*}{$x$} \\
\hline & I & II & III & IV & $\mathrm{V}$ & VI & VII & VIII & IX & $X$ & XI & XII & \\
\hline 2009 & -1.5 & 5.7 & 6.4 & 11.8 & 17.2 & 18.2 & 20.9 & 19.9 & 16.6 & 10 & 7.1 & 3.4 & 11.3 \\
\hline 2010 & 0.6 & 1.3 & 5.9 & 10.7 & 15.2 & 18.5 & 21.3 & 20.0 & 14.4 & 8.3 & 7.7 & 0.8 & 10.4 \\
\hline $\bar{x}$ & -0.45 & 3.5 & 6.15 & 11.25 & 16.2 & 18.35 & 21.1 & 19.95 & 15.5 & 9.15 & 7.4 & 2.1 & 10.8 \\
\hline
\end{tabular}

\section{RESULTS AND DISCUSSION}

Biomass yield: The average yield of both sudangrass biomass cultivars is shown in Table 3.

Table 3. Biomass yield of sudangrass in t/ha

\begin{tabular}{|c|c|c|c|c|c|c|c|c|c|c|}
\hline \multirow{2}{*}{\multicolumn{2}{|c|}{$\begin{array}{l}\text { Year } \\
\text { Treatments }\end{array}$}} & \multicolumn{3}{|c|}{2009} & \multicolumn{3}{|c|}{2010} & \multicolumn{3}{|c|}{$\bar{x} \quad 2009-2010$} \\
\hline & & $a_{1}$ & $a_{2}$ & $\bar{X}_{B}$ & $\mathrm{a}_{1}$ & $a_{2}$ & $\bar{x}_{B}$ & $\mathrm{a}_{1}$ & $\mathrm{a}_{2}$ & $\bar{x}_{B}$ \\
\hline \multicolumn{2}{|l|}{$\mathrm{b}_{1}$} & 16.9 & 29.15 & 23.02 & 16.8 & 27.75 & 22.27 & 16.82 & 28.45 & 22.63 \\
\hline \multicolumn{2}{|l|}{$\mathrm{b}_{2}$} & 13.0 & 12.32 & 12.66 & 12.0 & 10.34 & 11.17 & 12.5 & 11.33 & 11.91 \\
\hline \multicolumn{2}{|l|}{$\mathrm{b}_{3}$} & 2.25 & 3.07 & 2.66 & 2.05 & 2.77 & 2.41 & 2.15 & 2.92 & 2.53 \\
\hline \multicolumn{2}{|l|}{$\bar{X}_{A}$} & 10.71 & 14.84 & 12.78 & 10.28 & 13.62 & 11.95 & 10.49 & 14.23 & 12.36 \\
\hline \multirow{2}{*}{\multicolumn{2}{|c|}{$\begin{array}{l}\text { ANOVA } \\
\text { F }_{\text {calc. }}\end{array}$}} & $\bar{A}$ & B & $\mathrm{A} \times \mathrm{B}$ & $\bar{A}$ & B & $\mathrm{A} \times \mathrm{B}$ & A & B & $A \times B$ \\
\hline & & $6.0^{*}$ & $48.04 * *$ & $5.84 *$ & $8.57^{*}$ & $101.6 * *$ & $11.5 * *$ & $12.22 * *$ & $117.62 * *$ & $13.81 * *$ \\
\hline \multirow{2}{*}{ LSD } & 0.05 & 18.48 & \multicolumn{2}{|l|}{8.55} & 12.43 & \multicolumn{2}{|l|}{5.75} & 21.7 & \multicolumn{2}{|l|}{10.04} \\
\hline & 0.01 & 93.23 & \multicolumn{2}{|l|}{20.39} & 62.68 & \multicolumn{2}{|l|}{13.71} & 109.46 & \multicolumn{2}{|l|}{23.9} \\
\hline
\end{tabular}

The maximum production of sudangrass biomass (29.15 t/ha) was measured in the 'Piper Sweet' cultivar with a maximum rate of fertilization (in 2009). The lowest biomass yield ( $2.05 \mathrm{t} / \mathrm{ha}$ ) was measured in the 'Srem' cultivar in 2010. The average yield of biomass ranged from $2.41 \mathrm{t} /$ ha (in both cultivars in 2010) to 23.02 t/ha (in both cultivars grown under the starting fertilization and proper nitrogen nutrition). The total yield is lower compared to the possible potential of these species approximating to 100 t/ha (Glamočlija et al., 2010; Vučković, 1999; Sattell et al. 1998; Carter et al., 1989). In all the periods under consideration, the interaction of factors ranges from statistically significant to highly statistically significant (Figure 1). 


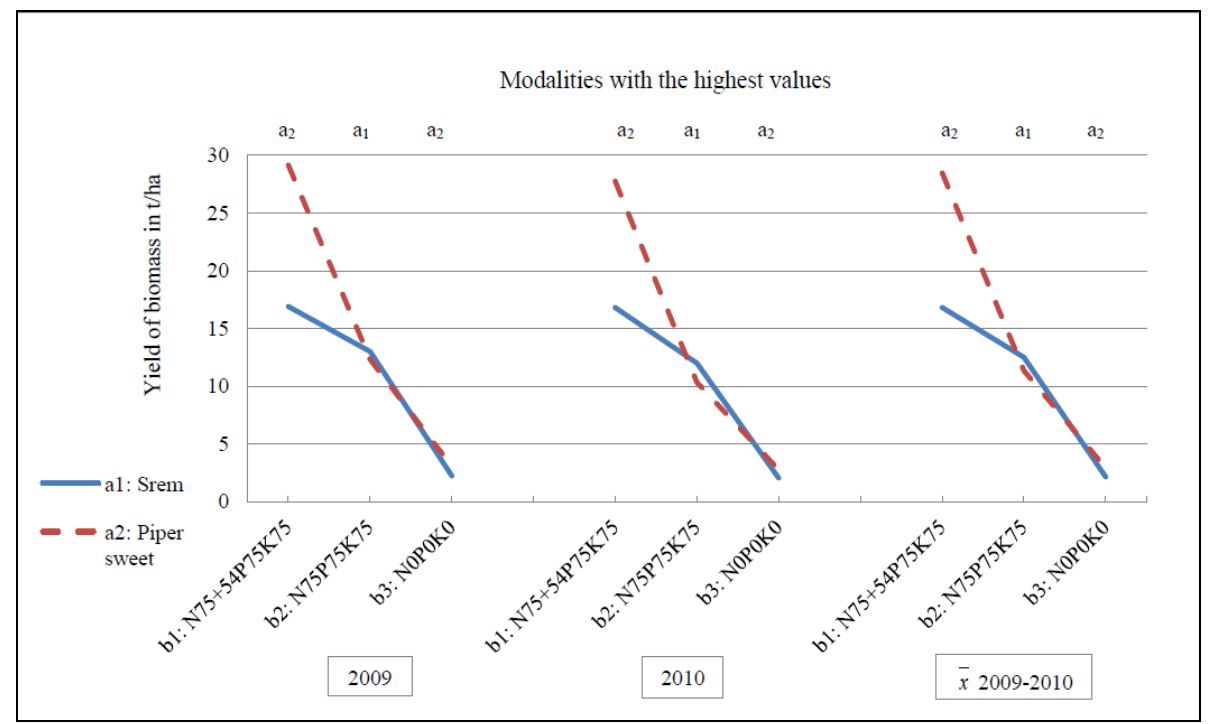

Figure 1. Effects of the interaction between Factor A and Factor B on the yield of sudangrass biomass

Figure 1 shows that the interaction between Factor A and Factor B was statistically significant in 2009, and highly statistically significant in 2010. The Factor A (cultivar type) effect is statistically significant in 2009 and 2010, and highly statistically significant regarding its average values. Factor B (fertilization) is highly statistically significant in all time intervals. This means that the biomass yield, in certain years, depends on the mutual and immediate reaction of the cultivars selected and nitrate fertilization treatment applied, depending also on climatic conditions during the year.

The biomass yield of 'Piper Sweet' is slightly lower compared to the earlier yield of this cultivar. During 2007 and 2008, in the Deposol of the external overburden deposition site plateau Raškovac - the Stanari open pit, the biomass yield was $40 \mathrm{t} / \mathrm{ha}$ in the first cutting (Malić, 2010).

According to the results of the biomass yield (Table 3), it is evident that nutrients from the mineral fertilizers applied, particularly nitrogen, positively influenced the biomass of sudangrass.

Dry matter yield: The formed dry matter represents a potential for a possible synthesis of humus matter. This would mark the first stage in enhancing the fertility of the Deposol soil. Table 4 shows the average values of dry matter of the sudangrass tops, which is ploughed (incorporated) in the surface layer of the Deposol plot.

Table 4. Dry matter of ploughed sudangrass in $\mathrm{t} / \mathrm{ha}$

\begin{tabular}{|c|c|c|c|c|c|c|c|c|c|c|}
\hline \multirow{2}{*}{\multicolumn{2}{|c|}{$\begin{array}{l}\text { Year } \\
\text { Treatments }\end{array}$}} & \multicolumn{3}{|c|}{2009} & \multicolumn{3}{|c|}{2010} & \multicolumn{3}{|c|}{$\bar{x} \quad 2009-2010$} \\
\hline & & $\mathrm{a}_{1}$ & $\mathrm{a}_{2}$ & $\overline{\bar{x}_{B}}$ & $\mathrm{a}_{1}$ & $\mathrm{a}_{2}$ & $\overline{\bar{x}_{B}}$ & $\mathrm{a}_{1}$ & $\mathrm{a}_{2}$ & $\overline{\bar{x}} \bar{B}_{B}$ \\
\hline \multicolumn{2}{|l|}{$\mathrm{b}_{1}$} & 5.9 & 10.3 & 8.1 & 4.75 & 9.5 & 7.12 & 5.32 & 9.9 & 7.61 \\
\hline \multicolumn{2}{|l|}{$\mathrm{b}_{2}$} & 3.85 & 4.3 & 4.07 & 4.1 & 3.5 & 3.8 & 4.02 & 3.9 & 3.96 \\
\hline \multicolumn{2}{|l|}{$b_{3}$} & 1.1 & 1.65 & 1.37 & 0.95 & 1.52 & 123 & 1.02 & 1.58 & 1.3 \\
\hline \multicolumn{2}{|l|}{$\bar{X}_{A}$} & 3.61 & 5.41 & 4.51 & 3.26 & 4.84 & 4.05 & 3.45 & 5.12 & 4.29 \\
\hline \multirow{2}{*}{\multicolumn{2}{|c|}{$\begin{array}{l}\text { ANOVA } \\
F_{\text {calc. }}\end{array}$}} & $\mathrm{A}$ & B & $\mathrm{A} \times \mathrm{B}$ & A & B & $\mathrm{A} \times \mathrm{B}$ & $\mathrm{A}$ & $\mathrm{B}$ & $\mathrm{A} \times \mathrm{B}$ \\
\hline & & 13.86* & $91.45^{* *}$ & $10.42 *$ & $0,09^{--}$ & $79.45 * *$ & $0.75 * *$ & $21.47 * *$ & $115.62^{* *}$ & $3.7 * *$ \\
\hline \multirow{2}{*}{ LSD } & 0.05 & 5.17 & \multicolumn{2}{|l|}{26.09} & - & \multicolumn{2}{|l|}{3.7} & 3.9 & \multicolumn{2}{|l|}{1.81} \\
\hline & 0.01 & 2.39 & \multicolumn{2}{|l|}{5.7} & - & \multicolumn{2}{|l|}{8.8} & 19.7 & \multicolumn{2}{|l|}{\begin{tabular}{|l|}
4.31 \\
4.31
\end{tabular}} \\
\hline
\end{tabular}

The maximum value of dry matter of $10.3 \mathrm{t} /$ ha was measured in the plots with the highest biomass production, i.e. in the 'Piper Sweet' cultivar in 2009. The lowest value of dry matter ( $0.95 \mathrm{t} / \mathrm{ha})$ was recorded in the 'Srem' cultivar in 2010. Based on the highest yields obtained (the highest yield of biomass was 29.15 t/ha and dry matter was 10.30 
t/ha), green manuring proved successful because every dry matter yield of more than 5 t/ha exerts a positive effect (Todorović et al., 2003).

The average values of the dry matter ranged from $1.23 \mathrm{t} /$ ha (measured in 2010 in the control plots) to 8.1 t/ha (in the treatments with a starting fertilizer and nutrients in both cultivars in 2009). The plots with a maximum biomass production (treatments: a2b1 in 2009 and 2010) indicated the largest increase in organic matter in Deposol (max values: 10.3 in 2009 and 9.5 in 2010). These findings are in agreement with previous research on green manure under the same agro-ecological conditions (Malić, 2010). In all three periods under consideration, the interaction effects of Factor A and B were identified (Figure 2).

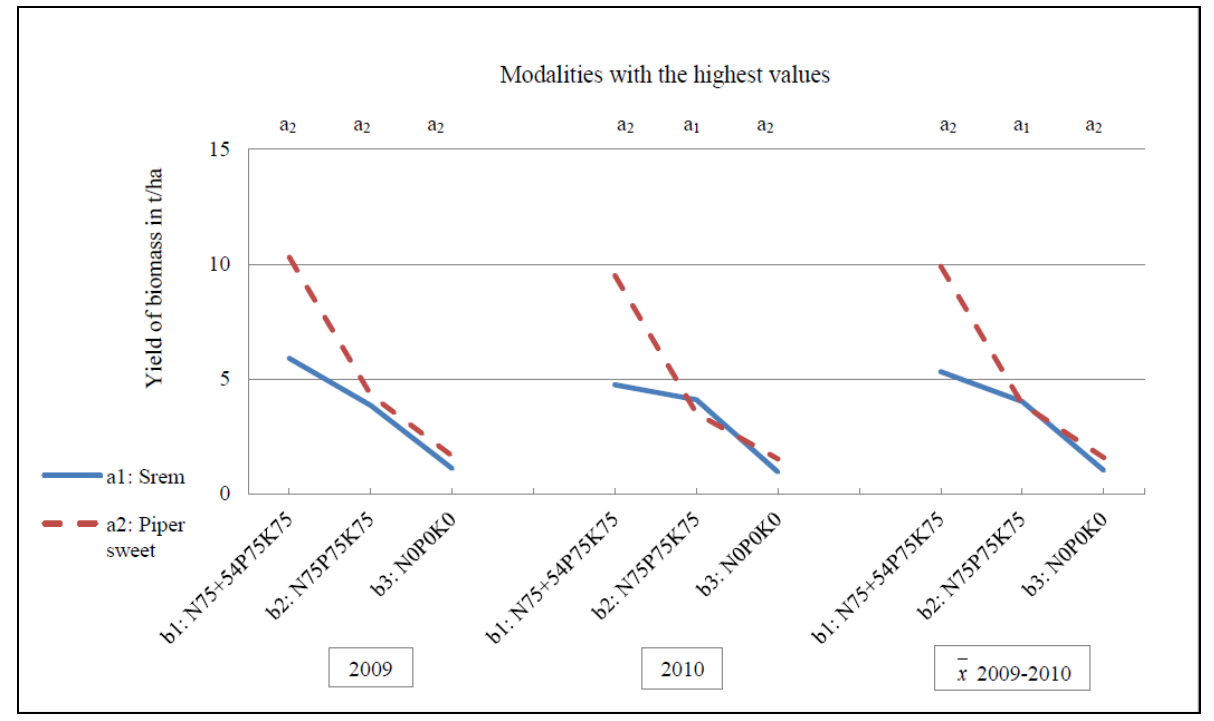

Figure 2. The interactive effects of Factor A and B on the content of sudangrass dry matter

The interaction of both basic factors is statistically significant in 2009, and highly statistically significant in 2010 year and regarding their average values. The Factor A activity is statistically significant in 2009, and highly significant regarding its average values, whereas the Factor A activity was not significant in 2009. Factor B is highly statistically significant in all time intervals.

In previous research, including a laboratory analysis of these Deposols, Malić and Marković (2012) stated that three years of cultural and biological practices were required for a moderate improvement of the fertility of Deposol in the reclamation process. The same authors stated that the application of green manure and cultivation of the field crops for three successive years can increase the organic matter content in the soil by $2 \%$. The increase of organic matter and humus content in this technogenic soil is one of the main characteristics of the ameliorated Deposol (Malić, 2010). Nitrogen fertilization, accompanied by starter fertilizers, additionally increases the yield, which is in accordance with previous studies (Zerbini and Thomas, 2003).

Differences in the value of organic matter between the examined cultivars showed a statistical significance in 2009 (a precipitation amount of $433.6 \mathrm{~mm}$ in the vegetation period), and in 2010 (a precipitation amount of $892.8 \mathrm{~mm}$ in the vegetation period), but there were no differences between the cultivars. Therefore, it can be concluded that foreign cultivars of sudangrass 'Piper Sweet' produce better results under extreme climatic conditions (in years with less precipitation), compared to the cultivar 'Srem'.

\section{CONCLUSION}

The results obtained emphasize that it is necessary to select proper cultural practices when planting sudangrass in the reclamation of Stanari Deposols. The highest yields of biomass (29.15 t/ha) and dry matter (10.30 t/ha) were recorded in the 'Piper Sweet' cultivar in 2009, with a maximum rate of fertilization. The lowest yields of biomass (2.05 t/ha) and dry matter (0.95 t/ha) were observed in the cultivar 'Srem' in 2010. The proper selection of cultivars and fertilization methods are very important in order to achieve the maximum yield of biomass, which is directly correlated with the climatic characteristics during the experimental year. Higher biomass yields directly increase the organic matter content of technosols, i.e. of Deposol. The 'Piper Sweet' cultivar showed far superior results 
compared to the 'Srem' cultivar. In order to increase the content of organic matter in the surface layer of Deposol, Sorghum sp. varieties can be successfully cultivated in these agro-ecological (technosols) areas.

\section{REFERENCES}

CARTER R, HICKS R, OPLINGER S, DOLL D, BUNDY G, SCHULER T, HOLMES J: Grain Sorghum (Milo). Field Crops Manual, 1989. Retrieved from: https://hort.purdue.edu/newcrop/afcm/sorghum. html

ĆUPINA B, PEJIĆ B, ERIĆ P, KRSTIĆ Đ, VUČKOVIĆ S: Specifičnosti u tehnologiji proizvodnje krmnog sirka i sudanske trave u agroekološkim uslovima Vojvodine. Zbornik radova Instituta za ratarstvo i povrtarstvo, 44(1), pp. 291-300, 2007.

GLAMOČLIJA Đ, DRAŽIĆ Gordana, IKANOVIĆ Jela, MALETIĆ R, JANKOVIĆ S, MILOVANOVIĆ J, RAKIĆ, S: Uticaj povećanih količina azota na prinos zelene biomase i sena krmnog sirka, sudanske trave i interspecijes hibrida. Journal of Scientific Agricultural Research, 71(2), pp. 63-74, 2010.

KNEŽIČEK Ž, ULJIĆ H, HUSAGIĆ R: Oblikovanje i prenamjena prostora površinskih kopova lignita. Rudarski institut Tuzla, 2006.

LONČAR S, ĐUROVIĆ Mirjana, TRBIĆ M, MALIĆ N: Presjek dugoročnog plana rekultivacije površinskih kopova ugljenog basena Stanari. Zbornik radova VIII međunarodne konferencije "Nemetali 2009". Vrujci, pp. 126-133, 2009.

MALIĆ N and MARKOVIĆ M: Promjene pedoloških karakteristika Deposola u rekultivaciji. Agroznanje, 13(3), pp. 463-474, 2012.

MALIĆ N: Rekultivacija stanarskih deposola primjenom agromeliorativnih mjera i sjetvom travno-leguminoznih smjesa. PhD Thesis. Poljoprivredni fakultet Univerziteta u Banjaluci, 2015.

MALIĆ N: Sideracija kao agrotehnička faza eurekultivacije spoljašnjeg odlagališta površinskog kopa Raškovac - Stanari. MS Thesis. Poljoprivredni fakultet Univerziteta u Banjaluci, 2015.

MALIĆ N, BIJELIĆ V, KOVAČEVIĆ G: Rekultivacija tehnogenih zemljišta u Republici Srpskoj. Zbornik radova I Međunarodnog simpozijuma "Savremene tehnologije u rudarstvu i zaštiti životne sredine - Rudarstvo 2010". Tara - Srbija, pp. 437-444, 2010.

MARSHALIS A, ANGADI V, CONTRERAS GOVEA E: Dry matter yield and nutritive value of corn, forage sorghum and BMR forage sorghum at didderent plant populations and nitrogen rates. Field Crops Research 116 (1-2), pp. 52-57, 2010.

RESULOVIĆ H, ČUSTOVIĆ H: Technosols - Development, Classification and Use. Agriculturae Conspectus Scientificus 72 (1), pp. 13-16, 2007.

RESULOVIĆ H: Zemljišni resursi u BiH - korištenje u funkciji održivog razvoja. Posebna izdanja ANU BiH, Knjiga CIX "Korištenje tla i vode u funkciji održivog razvoja i zaštite okoliša". Knjiga 16. Sarajevo, pp. 33-44, 1999.

SATTELL R, DICK R, INGHAM R, KAROW R, MCGRATH D: Sudangrass and Sorghum - Sudangrass Hybrids. Oregon Cover Crops: Oregon State University, 1998. Retrieved from: http://extension.oregonstate.edu/catalog/html/em/em8703

TODOROVIĆ J, LAZIĆ Branka, KOMLJENOVIĆ I: Ratarsko - povrtarski priručnik. Grafo Mark, Laktaši, pp. 85-91, 2003.

VUČKOVIĆ S: Krmno bilje (monografija). Institut za istraživanja u poljoprivredi "Srbija", Beograd, pp. 122-131, 1999.

VUJIĆ S, CVEJIĆ JASMINKA, MILJANOVIĆ I, DRAŽIĆ Dragana: Projektovanje rekultivacije i uređenja predela površinskih kopova. Rudarsko-geološki fakultet Univerziteta u Beogradu i Akademija inženjerskih nauka Srbije, 2009.

ZERBINI E, THOMAS D: Opportunities for improvement of nutritive value in sorghum and pearl millet residues in South Asia through genetic enhancement. Field Crop Research. 84, pp. 3-15, 2003.

FAO, IUSS Working Group WRB: World Reference Base for Soil Resources, 2014, update 2015. Retrieeved from: www.fao.org/3/a-i3794e.pdf 


\title{
SUDANSKA TRAVA (Sorghum sudanense PERS.) U REKULTIVACIJI TEHNOSOLA U RUDNIKU STANARI
}

\author{
Nenad MALIĆ , Una MATKO STAMENKOVIĆ, Mihajlo MARKOVIĆ ,Zlatan KOVAČEVIĆ
}

Rezime. Površinsku eksploataciju mineralnih sirovina prate promjene u životnoj sredini, što utiče i na degradaciju zemljišnih površina.. U radu su prikazani rezultati gajenja sudanske trave (Sorghum sudanense Pers.) u rekultivaciji deposola (tehnosoli) u rudniku Stanari. Primjenjeno gajenje sudanske trave metodom zelenišnog đubrenja deposola predstavlja agrotehničku fazu rekultivacije. Cilj istraživanja je povećanje sadržaja organske materije u površinskom sloju deposola. Istraživanja su obavljena na eksperimentalnoj parceli tehnogenog zemljišta unutrašnjeg odlagališta otkrivke sa površinskog kopa Raškovac, rudnika uglja Stanari, u dvogodišnjem periodu (2009/2010). Kod dvije sorte sudanske trave (faktor A) primjenjena su tri tretmana đubrenja (faktor B). Analiza zemljišnih uslova eksperimentalne parcele pokazuje da se radi o pjeskovitom deposolu dosta niske plodnosti. Najveći prosječni prinos zelene mase $(29,15 \mathrm{t} / \mathrm{ha}) \mathrm{i}$ suve materije $(10,03 \mathrm{t} / \mathrm{ha})$ izmjereni su na tretmanima sa punom primjenom mineralnih đubriva kod sorte piper sweet u 2009. godini. Najmanji prosječni prinos zelene mase $(2,05 \mathrm{t} / \mathrm{ha})$ i suve materije $(0,95 \mathrm{t} / \mathrm{ha}) \mathrm{je}$ postigla sorta srem na kontroli u 2010. Statistički značajne razlike su prisutne između primijenjenih tretmana a i godine praćenja su pokazale uticaj. Samo upotrebom odgovarajuće sorte sudanske trave i pravilnom primjenom đubrenja sa všim dozama azota obezbjeđuje se značajno povećanje organske materije u deposolu.

Ključne riječi: biomasa, sorta đubrenje, deposol, Stanari

Received / Primljen: 02.10.2017. Accepted / Prihvaćen: 25.12.2017. 